Check for updates

Cite this: RSC Adv., 2017, 7, 32826

\title{
Electricity generation in a microbial fuel cell using yogurt wastewater under alkaline conditions
}

Received 1st June 2017

Accepted 21st June 2017

DOI: $10.1039 / \mathrm{c} 7 \mathrm{ra06131e}$

rsc.li/rsc-advances

\author{
Haiping Luo, Guofang Xu, Yaobin Lu, Guangli Liu, (DD* Renduo Zhang, Xiao Li, \\ Xiyuan Zheng and Meihan Yu
}

\begin{abstract}
The aim of this study was to investigate the feasibility of electricity generation in a microbial fuel cell (MFC) using yogurt wastewater as the substrate under alkaline conditions. Different initial COD concentrations of yogurt wastewater (i.e., $1.0 \pm 0.1,2.0 \pm 0.1,5.0 \pm 0.5,8.0 \pm 0.6$, and $13.0 \pm 1.0 \mathrm{~g} \mathrm{~L}^{-1}$ ) at pH 10.5 were tested in the single-chamber air-cathode MFC. The maximum power density reached $1043 \pm 100 \mathrm{~mW} \mathrm{~m}^{-2}$, which was much higher than those previously reported using food-processing wastewater under alkaline conditions. The COD and $\mathrm{NH}_{4}-\mathrm{N}$ removal efficiencies were more than $87 \%$ and $74 \%$, respectively. With the increase of COD concentration in yogurt wastewater, the internal resistance in the MFC increased but the bacterial viability in the anode biofilm decreased, resulting in a decrease of electricity generation in the MFC. Geoalkalibacter with a relative abundance of $12.9-49.9 \%$ dominated the bacterial community in the anode biofilm. Our results should be useful in expanding the application scope of MFCs in wastewater treatment under alkaline conditions.
\end{abstract}

\section{Introduction}

High electricity consumption is required in many wastewater treatment processes, which accounts for $\sim 3 \%$ of the total electricity usage in the USA. ${ }^{1}$ In a typical municipal wastewater treatment plant, the chemical energy in the organic compounds of wastewater is much higher than the electricity needed for the wastewater treatment $\left(\sim 0.6 \mathrm{~kW} \mathrm{~h} \mathrm{~m}^{-3}\right) .{ }^{1}$ In the microbial fuel cell (MFC), electrochemically active bacteria (EAB) in the anode can convert the chemical energy in organic compounds directly into electricity. ${ }^{2-4}$ The wastewater in the food-processing industries has abundant organics with easy biodegradability, thus it is possible to generate electricity from the food-processing wastewater using a MFC. ${ }^{5}$

The $\mathrm{pH}$ value in the anolyte is crucial to electricity generation of the MFC. It has been reported that alkaline conditions in anolyte can enhance electricity generation in the MFC. ${ }^{6-8}$ The maximum power density in the MFC with $\mathrm{pH} 9.0$ anolyte was $38.6 \%$ higher than that with $\mathrm{pH} 7.0$ using acetate as substrate. ${ }^{6}$ The coulombic efficiency (CE) increased from $43 \pm 10 \%$ at neutral $\mathrm{pH}$ to $60 \pm 5 \%$ at $\mathrm{pH} 9.5$ in the MFC fed with acetate. With anolyte $\mathrm{pH}$ increase from 7.0 to 9.5 , the relative abundance of Geobacter decreased from $79 \%$ to less than $1 \%$ and Geoalkalibacter increased from less than $1 \%$ to $21 \% .^{9}$ In the aircathode MFC with glucose as substrate, the maximum power density increased from 213 to $235 \mathrm{~mW} \mathrm{~m}^{-2}$ with $\mathrm{pH}$ in the

Guangdong Provincial Key Laboratory of Environmental Pollution Control and Remediation Technology, School of Environmental Science and Engineering, Sun Yat-sen University, Guangzhou, 510275, China.E-mail: liugl@mail.sysu.edu.cn solution increased from 10.0 to $11.0 .^{7}$ Previous studies also demonstrated that electricity could be produced in the MFC inoculated with marine consortia even with anolyte $\mathrm{pH}$ of 13 (7 $\left.\mathrm{mW} \mathrm{m}^{-2}\right) .{ }^{8}$ Many EABs can keep high activities under alkaline conditions. ${ }^{10-13}$ The maximum power density in the MFC inoculated with Shewanella oneidensis MR-1 increased by $\sim 2.5$ times when the analytic $\mathrm{pH}$ increased from 7.0 to 9.0 (102 vs. $40 \mathrm{~mW}$ $\mathrm{m}^{-2}$ ) using 5\% LB medium and 95\% M9 minimal medium. ${ }^{10}$ Using acetate as the substrate with $\mathrm{pH}=9.3$, halophilic Geoalkalibacter subterraneus DSM 23483 and alkaliphilic Geoalkalibacter ferrihydriticus DSM 17813 could produce electricity 5000-8300 and 2400-3300 $\mathrm{mA} \mathrm{m}{ }^{-2}$, respectively. ${ }^{11}$ The MFC with Pseudomonas alcaliphila strain MBR could produce the maximum current density of $71.0 \mathrm{~mA} \mathrm{~m}^{-2}$ at $\mathrm{pH} 9.5$ with sodium citrate as the substrate. ${ }^{12}$ Halanaerobium hydrogeniformans in the MFC could generate a maximum current density of $12.5 \mathrm{~mA} \mathrm{~m}{ }^{-2}$ at $\mathrm{pH} 11.0$ with formate as the substrate. ${ }^{13}$ However, the above studies of the MFCs were based on individual substrates or ideal media. Information is not available about MFC operation in real wastewater treatment under alkali conditions, different food-processing industry wastewaters have been tested in the MFC and performance of the MFC varies greatly with the wastewater compositions. ${ }^{5}$ The maximum power density of $111 \mathrm{~mW} \mathrm{~m}^{-2}$ was produced in the MFC using red wine lees with $\mathrm{pH} 7.0 \pm 0.2 .^{14}$ The MFC produced the maximum power density of $669 \mathrm{~mW} \mathrm{~m}^{-2}$ with brewery wastewater as the substrate at $\mathrm{pH} 6.5 \pm 0.4 .{ }^{15}$ In the slaughterhouse wastewater treatment, the maximum power density of $578 \mathrm{~mW}$ $\mathrm{m}^{-2}$ was observed in the MFC at $\mathrm{pH} 7.8 .^{16}$ However, foodindustry wastewater with higher $\mathrm{pH}$ values (e.g., >10.0) has 
not been tested in the MFC as far as we know. It is important to ascertain the performance of MFC using real wastewater with high $\mathrm{pH}$ values to expand the application field of MFC.

During the bottle washing procedure in many foodprocessing industries, such as beverage or yogurt production, the usage of sodium hydroxide result in $\mathrm{pH}$ values in wastewater $>11.0 .{ }^{17}$ The chemical oxygen demand (COD) in the yogurt wastewater can reach $136 \mathrm{~g} \mathrm{~L}^{-1}$. $^{5}$ It should be unique to test the performance of MFC using the yogurt wastewater as the substrate with high COD concentration as well as high $\mathrm{pH}$ value. $^{17}$.

The objective of this study is to explore the feasibility of electricity generation in the MFC using the yogurt wastewater as the substrate under the alkali condition. The performance of MFC was tested in terms of power density, internal resistance, COD removal, etc. The bacterial community in the anode biofilm was analyzed and discussed.

\section{Materials and methods}

\subsection{Yogurt wastewater}

The yogurt wastewater was taken from the bottled yogurt production line using returnable glass jars in a local dairy. The sediment pretreatment was used to remove the suspended solids in the wastewater. Because the yogurt wastewater was discharged in the batch mode in the factory, the quality of the yogurt wastewater was fluctuated greatly. The characteristics of the original yogurt wastewater was in a range of $\mathrm{pH}=6-11$, conductivity 1.5-4.0 mS cm ${ }^{-1}$, COD 0.8-14 $\mathrm{g} \mathrm{L}^{-1}$, ammonia 4.0$60 \mathrm{mg} \mathrm{L}^{-1}$, total nitrogen (TN) $20-350 \mathrm{mg} \mathrm{L}^{-1}$.

\subsection{MFC construction and operation}

The single-chamber air-cathode MFC was made of Perspex with a hole of $3 \mathrm{~cm}$ in diameter and $4 \mathrm{~cm}$ long. ${ }^{18,19}$ The effective volume was $28 \mathrm{~mL}$ in the MFC with three pieces of a stainless steel fiber felt ( $20 \mu \mathrm{m}, 316 \mathrm{~L}$ SS felt, Lier Filter Ltd., China) as the anode. Each piece had a projected surface area of $7 \mathrm{~cm}^{2}(2.98 \mathrm{~cm}$ in diameter) and was heated at $600{ }^{\circ} \mathrm{C}$ for $15 \mathrm{~min}$ before use. ${ }^{20}$ The air-cathode was prepared using a rolling method with activated carbon (SPC-01, Xinsen Carbon Co. Ltd., Fujian, China) as the catalyst and the effective projected surface area of cathode was $7 \mathrm{~cm}^{2} .{ }^{21}$ An external resistor of $1000 \Omega$ was used in the MFC throughout all the tests.

The matured MFCs fed by $1 \mathrm{~g} \mathrm{~L}^{-1}$ acetate and $50 \mathrm{mM}$ phosphate buffer solution were used to test the yogurt wastewater. The reactors were refreshed using a diluted yogurt wastewater with COD of $1 \mathrm{~g} \mathrm{~L}^{-1}$ at $\mathrm{pH}=8.5$. After a stabilized performance was reached, $\mathrm{pH}$ was gradually increased to 10.5. The total acclimation period was about one month when the electricity generation in the MFC became stable and repeatable at $\mathrm{pH}=10.5$. Then yogurt wastewaters with different COD values (i.e., $1.0 \pm 0.1,2.0 \pm 0.1,5.0 \pm 0.5,8.0 \pm 0.6,13.0 \pm 1.0 \mathrm{~g}$ $\mathrm{L}^{-1}$ ) were tested in the MFC, respectively, which were prepared using deionized water and the raw yogurt wastewater with a final volume of $28 \mathrm{~mL}$. To improve the conductivity and to control initial $\mathrm{pH}$ value of wastewater to 10.5 in the anolyte,
$50 \mathrm{mM}$ carbonate buffer solution was used throughout all the tests. The conductivity in the solution was kept at $\sim 6 \mathrm{mS} \mathrm{cm}^{-1}$ in all the tests. The experiments were carried out in duplicate at $30 \pm 1{ }^{\circ} \mathrm{C}$.

\subsection{Analysis and calculations}

The EIS measurements were carried out using an electrochemical station (Chenhua 660C, China). The anode and cathode electrodes were used as the counter and working electrodes, respectively. The calomel electrode (CHI150, Chenhua Co. Ltd, Shanghai, China) was used as the reference electrode. A frequency range of $100 \mathrm{kHz}$ to $100 \mathrm{mHz}$ with a sinusoidal perturbation of $5 \mathrm{mV}$ amplitude were used in all the EIS measurements. The total internal resistance in the MFC was divided into the ohmic and charge transfer resistances. The ohmic resistance $\left(R_{\Omega}\right)$ and charge transfer resistance $\left(R_{\mathrm{ct}}\right)$ were analyzed with Nyquist plot and simulated by the Zsimp Win software. ${ }^{19,22}$

COD concentration was determined using the standard titration method. ${ }^{23}$ The conductivity and $\mathrm{pH}$ were measured using a $\mathrm{pH}$ meter (Mettler Toledo, FE 30, Switzerland) and a conductivity meter (Mettler Toledo, FE 30K, Switzerland), respectively. Output voltages in the MFC were obtained by measuring the voltage across the external resistance of $1000 \Omega$ using a data acquisition system (2700, Keithley Instruments, Inc., USA). The power density and coulombic efficiency (CE) were calculated as previously reported. ${ }^{18}$ The polarization curve was obtained by changing the external resistances from 100 to $3000 \Omega .^{24}$

\subsection{The anode biofilm analysis}

Samples in the anode biofilms were stained with LIVE/DEAD Baclight staining kit (Molecular Probes, Invitrogen), and visualized using the Confocal laser scanning microscopy (CLSM, LSM 700, Zeiss) by distinguishing bacteria with high (green color) or low (red color) growth activities..$^{25,26}$ The biomass measurements on the anode biofilm were carried out using Coomassie light blue staining. ${ }^{22}$

The composition of bacterial communities in the anode biofilms were evaluated after at least 3 cycles of operation with a stable electricity generation. The total DNA of anode sample was extracted using DNA kit (12888-50, MOBIO, USA) according to manufacturer's protocol. The V3-V4 region of the 16S rDNA gene was amplified with the 338F (ACTCCTACGGGAGGCAGCA) and 806R (GGACTACVSGGGTATCTAAT). The PCR products were examined by $1 \%$ agarose gel electrophoresis and then sequenced on the Illumina Miseq platform (Majorbio BioPharm Technology Co., Ltd, Shanghai, China). The obtained results (raw sequencing reads) were submitted to the NCBI SRA database (accession number: SRP108185). The Shannon index was calculated to determine the microbial diversity in the anode biofilm. $^{22}$

\section{Results and discussion}

\subsection{Performance of MFCs under alkali condition}

The maximum power densities in the MFC decreased with the increase of COD concentrations in the anolyte. The maximum 
power density was $1043 \pm 104$ and $996 \pm 100 \mathrm{~mW} \mathrm{~m}^{-2}$ in the MFC with $1.0 \pm 0.1 \mathrm{~g} \mathrm{~L}^{-1}$ and $2.0 \pm 0.1 \mathrm{~g} \mathrm{~L}^{-1}$ of COD in the anolyte, respectively (Fig. 1A). The maximum power densities with $5.0 \pm 0.5,8.0 \pm 0.6,13.0 \pm 1.0 \mathrm{~g} \mathrm{~L}^{-1} \mathrm{COD}$ values in the anolyte were only $69 \%\left(722 \pm 70 \mathrm{~mW} \mathrm{~m}^{-2}\right), 54 \%(567 \pm 60 \mathrm{~mW}$ $\left.\mathrm{m}^{-2}\right), 21 \%\left(221 \pm 20 \mathrm{~mW} \mathrm{~m}^{-2}\right)$ of that with $1.0 \pm 0.1 \mathrm{~g} \mathrm{~L}^{-1} \mathrm{COD}$, respectively. Correspondingly, the internal resistances in the MFCs gradually increased from $113 \pm 10 \Omega\left(1.0 \pm 0.1 \mathrm{~g} \mathrm{~L}^{-1}\right.$ COD) to $464 \pm 40 \Omega\left(13.0 \pm 1.0 \mathrm{~g} \mathrm{~L}^{-1} \mathrm{COD}\right)$ with the increase of COD concentrations (Fig. 1B).

The CEs and operation time per cycle in the MFC with different COD concentrations of yogurt wastewater in the anolyte are shown in Fig. 2. The high COD concentrations in the anolyte resulted in low CEs of the MFC. The CEs decreased from $23 \pm 3 \%$ to $5 \pm 1 \%$ with the COD increasing from $1.0 \pm$ 0.1 to $13.0 \pm 1.0 \mathrm{~g} \mathrm{~L}^{-1}$. The CEs were $16 \pm 2 \%, 12 \pm 2 \%$, and 10 $\pm 2 \%$ for COD of $2.0 \pm 0.1,5.0 \pm 0.5$, and $8.0 \pm 0.6 \mathrm{~g} \mathrm{~L}^{-1}$, respectively. The operation time per cycle in the MFC was $44 \pm$ $8,60 \pm 8,150 \pm 15,174 \pm 18$ and $240 \pm 25 \mathrm{~h}$ when the COD concentration of the yogurt wastewater in the anolyte was 1.0 $\pm 0.1,2.0 \pm 0.1,5.0 \pm 0.5,8.0 \pm 0.6$, and $13.0 \pm 1.0 \mathrm{~g} \mathrm{~L}^{-1}$, respectively.

The COD, $\mathrm{NH}_{4}-\mathrm{N}$, and $\mathrm{TN}$ removals in the MFCs were determined using different yogurt wastewaters as shown in
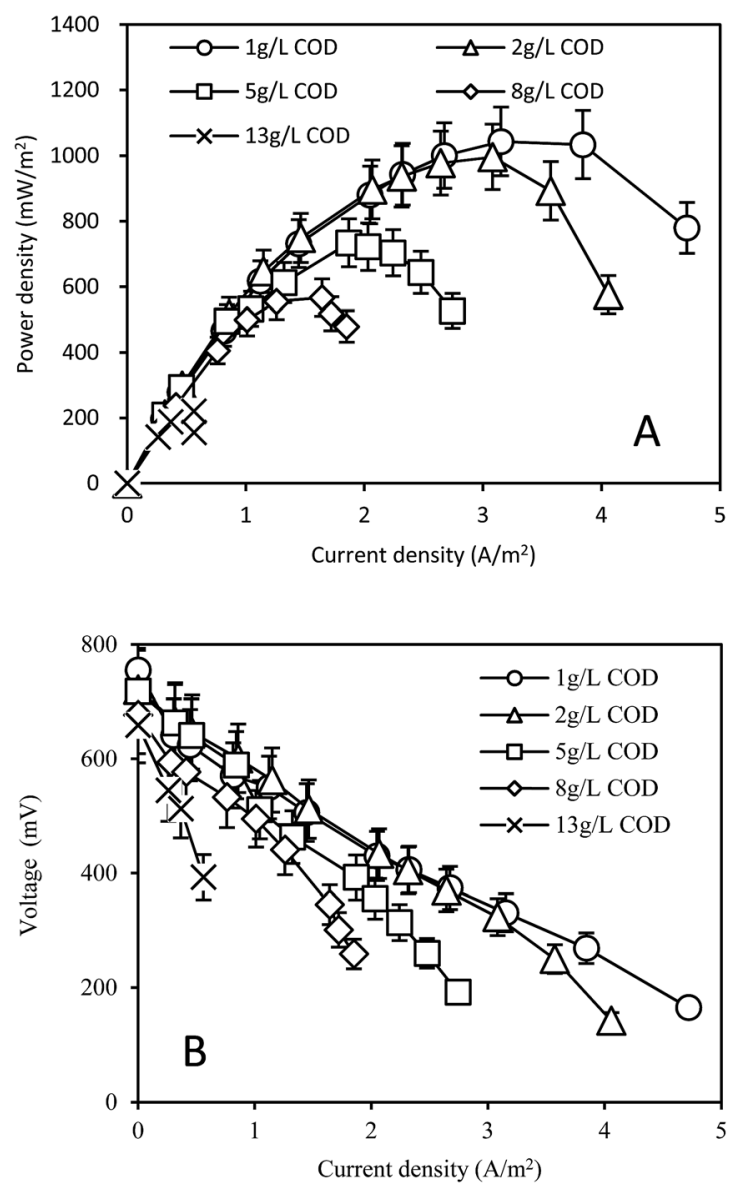

Fig. 1 (A) Power density and (B) voltage outputs in the MFC fed by yogurt wastewater with different COD concentrations.

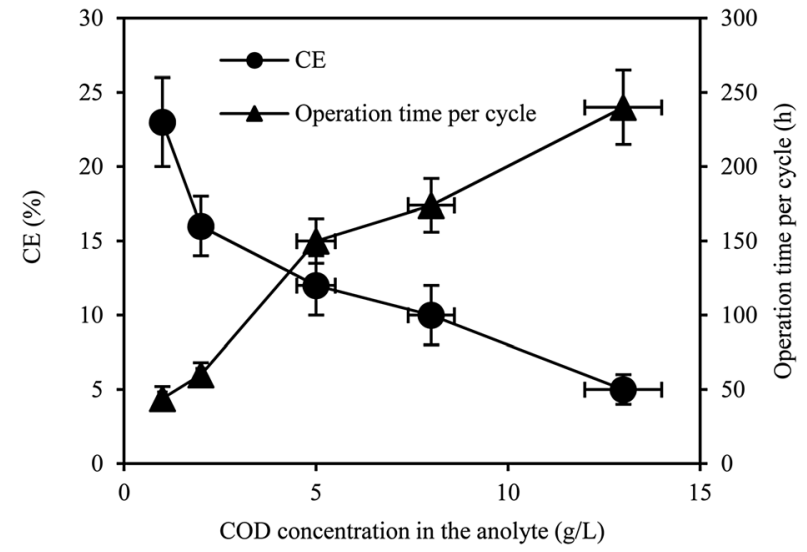

Fig. 2 The CE and operation time per cycle in the MFC fed by yogurt wastewater with different COD concentrations.

Table 1. The COD removals were higher than $85 \%$ with the different initial COD concentrations used in the MFC. Efficient denitrification occurred in the MFC under different initial concentrations of $\mathrm{NH}_{4}-\mathrm{N}$ and TN. The $\mathrm{NH}_{4}-\mathrm{N}$ removal reached $96 \pm 4 \%$ within $44 \pm 8 \mathrm{~h}$ under the initial $\mathrm{NH}_{4}-\mathrm{N}$ concentration of $4.3 \pm 0.5 \mathrm{mg} \mathrm{L}{ }^{-1}$. With the initial $\mathrm{NH}_{4}-\mathrm{N}$ concentration increased to $50.0 \pm 5.0 \mathrm{mg} \mathrm{L}^{-1}, 75 \pm 8 \%$ of the $\mathrm{NH}_{4}-\mathrm{N}$ removal was achieved within $240 \pm 25 \mathrm{~h}$. The TN removal was $69 \pm 3 \%$ within $44 \pm 8 \mathrm{~h}$ under the initial TN concentration of $26 \pm 4 \mathrm{mg} \mathrm{\textrm {L } ^ { - 1 }}$. The final TN concentration gradually increased from $14 \pm 3$ to $51 \pm 5 \mathrm{mg} \mathrm{L}^{-1}$ with the increase of the initial TN concentrations from $49 \pm 6$ to $303 \pm$ $30 \mathrm{mg} \mathrm{L}^{-1}$. Nevertheless, the TN removals could be kept at more than $69 \%$ throughout all the tests. Simultaneous nitrification and denitrification, volatilization, and assimilation could occur in the single-chamber air-cathode MFC, resulting in high nitrogen removal as previously reported. ${ }^{27,28}$

Many factors could affect the MFC performance, including types of substrate, reactor configuration, etc., thus it was difficult to make full assessment on our results. A preliminary comparison between our results and those in the literature was carried out (Table 2). The maximum power density in our MFC with yogurt wastewater was much higher than those previously reported with yogurt wastewater or dairy wastewater. With the same initial COD of $1.0 \mathrm{~g} \mathrm{~L}^{-1}$ under $\mathrm{pH} 10.0$, the maximum power density yogurt wastewater in our study was 6.47 times higher than that with dairy wastewater, $(1043 \pm 100 v s .161 \mathrm{~mW}$ $\left.\mathrm{m}^{-2}\right) .{ }^{17}$ With the similar initial COD of $8.0 \mathrm{~g} \mathrm{~L}^{-1}$, the maximum power density in our MFC was 12.9 times higher than that using yogurt wastewater under $\mathrm{pH} 6.15\left(567 \pm 50\right.$ vs. $\left.44 \mathrm{~mW} \mathrm{~m}^{-2}\right) .{ }^{5}$. The performance of our MFC with yogurt wastewater was also comparable to that with acetate, glucose, etc. $^{6-8}$ The maximum power density of our MFC was 1.25 and 34.1 times higher than that with acetate as the substrate under $\mathrm{pH} 9.5(1043 \pm 100 v s$. $\left.833 \mathrm{~mW} \mathrm{~m}^{-2}\right)$, and acetate + petone under $\mathrm{pH} 11.0(1043 \pm 100$ vs. $30 \mathrm{~mW} \mathrm{~m}^{-2}$ ), respectively. In addition, it was the first time to report electricity generation in the MFC with real wastewater under $\mathrm{pH} 10.5$ as far as we know. 
Table 1 The initial and final concentrations of $\mathrm{COD}, \mathrm{NH}_{4}-\mathrm{N}$, and $\mathrm{TN}$ in the $\mathrm{MFC}$ with yogurt wastewater as the substrate under $\mathrm{pH}=10.5$

\begin{tabular}{|c|c|c|c|c|c|c|c|c|}
\hline Initial $\left(\mathrm{g} \mathrm{L}^{-1}\right)$ & Final $\left(\mathrm{g} \mathrm{L}^{-1}\right)$ & Removal (\%) & Initial $\left(\mathrm{mg} \mathrm{L}^{-1}\right)$ & Final $\left(\mathrm{mg} \mathrm{L} \mathrm{L}^{-1}\right)$ & Removal (\%) & Initial $\left(\mathrm{mg} \mathrm{L}^{-1}\right)$ & $\begin{array}{l}\text { Final (mg } \\
\left.\mathrm{L}^{-1}\right)\end{array}$ & Removal (\%) \\
\hline COD & & & $\mathrm{NH}_{4}-\mathrm{N}$ & & & $\mathrm{TN}$ & & \\
\hline $1.0 \pm 0.1$ & $0.12 \pm 0.05$ & $88 \pm 7$ & $4.3 \pm 0.5$ & $0.2 \pm 0.1$ & $96 \pm 4$ & $26 \pm 4$ & $8 \pm 1$ & $69 \pm 3$ \\
\hline $2.0 \pm 0.1$ & $0.20 \pm 0.05$ & $89 \pm 8$ & $8.2 \pm 0.7$ & $0.7 \pm 0.4$ & $91 \pm 6$ & $49 \pm 6$ & $14 \pm 3$ & $72 \pm 3$ \\
\hline $5.0 \pm 0.5$ & $0.28 \pm 0.05$ & $95 \pm 5$ & $22.6 \pm 3.0$ & $2.7 \pm 0.5$ & $88 \pm 9$ & $129 \pm 14$ & $40 \pm 4$ & $69 \pm 2$ \\
\hline $8.0 \pm 0.6$ & $0.29 \pm 0.05$ & $96 \pm 4$ & $35.8 \pm 4.0$ & $3.2 \pm 0.5$ & $91 \pm 6$ & $204 \pm 20$ & $46 \pm 5$ & $77 \pm 2$ \\
\hline $13.0 \pm 1.0$ & $0.40 \pm 0.6$ & $97 \pm 3$ & $50.0 \pm 5.0$ & $12.5 \pm 1.5$ & $75 \pm 8$ & $303 \pm 30$ & $51 \pm 5$ & $83 \pm 2$ \\
\hline
\end{tabular}

Table 2 Comparison of the MFC performances with different substrates under different $\mathrm{pH}$ values

\begin{tabular}{|c|c|c|c|c|c|c|c|}
\hline Substrate & MFC configuration & $\begin{array}{l}\mathrm{pH} \text { in } \\
\text { the anolyte }\end{array}$ & $\begin{array}{l}\text { Influent COD } \\
\text { concentration }\left(\mathrm{g} \mathrm{L}^{-1}\right)\end{array}$ & $\begin{array}{l}\text { COD removal } \\
(\%)\end{array}$ & $\begin{array}{l}\text { Maximum power } \\
\text { density }\left(\mathrm{mW} \mathrm{m}^{-2}\right)\end{array}$ & CE $(\%)$ & Ref. \\
\hline Acetate & $\begin{array}{l}\text { Single-chamber } \\
\text { air-cathode MFC }\end{array}$ & 9.5 & $-^{a}$ & - & 833 & - & 6 \\
\hline $\begin{array}{l}\text { Glucose }+ \\
\text { yeast extract }\end{array}$ & $\begin{array}{l}\text { Single-chamber } \\
\text { air-cathode MFC }\end{array}$ & 10.0 & 2.2 & $81 \pm 7$ & 213 & $19.8 \pm 2.3$ & 7 \\
\hline Acetate + petone & Dual-chamber MFC & 11.0 & $-^{b}$ & 42 & 30 & - & 8 \\
\hline Dairy wastewater & $\begin{array}{l}\text { Single-chamber MFC with } \\
\text { spiral anode }\end{array}$ & $\sim 10.0$ & 1.0 & 91 & $161\left(20.2 \mathrm{~W} \mathrm{~m}^{-3}\right)$ & 27 & 17 \\
\hline $\begin{array}{l}\text { Dairy industry } \\
\text { wastewater }\end{array}$ & Dual-chamber MFC & 7.0 & 3.6 & 90 & 621 & 37 & 31 \\
\hline Yogurt waste & Dual-chamber MFC & 6.15 & 8.2 & - & 44 & - & 5 \\
\hline Yogurt & Single-chamber & 10.5 & $1.0 \pm 0.1$ & $88 \pm 7$ & $1043 \pm 100$ & $23 \pm 3$ & This \\
\hline
\end{tabular}

${ }^{a} 20-30 \mathrm{mM}$ acetate. ${ }^{b} 1 \mathrm{~g} \mathrm{~L}^{-1}$ acetate and $1.25 \mathrm{~g} \mathrm{~L}^{-1}$ petone.

\subsection{EIS measurements on the MFCs with different yogurt wastewater}

The internal resistances in the MFCs with different yogurt wastewaters were determined by the EIS measurements (Fig. 3). The total internal resistances in the MFC were in the following order: $101 \pm 10 \Omega<127 \pm 13 \Omega<172 \pm 18 \Omega<190 \pm 20 \Omega<380$ $\pm 40 \Omega$ with increase in COD concentration of the feed from 1.0 $\pm 0.1,2.0 \pm 0.1,5.0 \pm 0.5,8.0 \pm 0.6$, to $13.0 \pm 1.0 \mathrm{~g} \mathrm{~L}^{-1}$. The change of the total internal resistances based on the EIS measurements was consistent with that determined by the polarization curves, but with some differences between these methods. ${ }^{32}$ The ohmic resistance in the MFC had the same order as the total internal resistance as follows: $73 \pm 8 \Omega<93 \pm$ $10 \Omega<136 \pm 15 \Omega<152 \pm 15 \Omega<265 \pm 25 \Omega$ with increase in COD concentration of the feed from $1.0 \pm 0.1,2.0 \pm 0.1,5.0 \pm$ $0.5,8.0 \pm 0.6$, to $13.0 \pm 1.0 \mathrm{~g} \mathrm{~L}^{-1}$. The charge transfer resistances in the MFC were increased from $28 \pm 4 \Omega$ to $114 \pm 15 \Omega$ with increase in COD concentration of the feed from $1.0 \pm 0.1$ to $13.0 \pm 1.0 \mathrm{~g} \mathrm{~L}^{-1}$. High charge transfer resistance in the MFC indicated that the electrochemical activity of the anode biofilm was decreased. ${ }^{33}$ Limiting the electrochemical activity of the anode biofilm, higher concentrations of yogurt wastewater increased the internal resistance in the MFC.

\subsection{CLSM measurements on the anode biofilms of MFCs}

The bacterial viability in the anode biofilm was determined using the CLSM measurement (Fig. 4). Similar bacteria viability (about $75 \pm 7 \%$ ) was observed under the initial COD concentrations from $1.0 \pm 0.1$ to $5.0 \pm 0.5 \mathrm{~g} \mathrm{~L}^{-1}$ in the yogurt wastewater. However, the bacteria viability decreased to $67 \pm 3 \%$ and $63 \pm 5 \%$ under the initial COD concentrations of $8.0 \pm 0.6$ and $13.0 \pm 1.0 \mathrm{~g} \mathrm{~L}^{-1}$, respectively. The bacterial viability can change from $20 \%$ to $95 \%$ in the anode biofilm in the MFC, depending on the substrate, exoelectrogens, etc. ${ }^{25,26}$

Our results indicated that high concentration of organics could inhibit the bacterial activity. The biomass on the anode biofilm slightly increased from $1.75 \pm 0.14 \mathrm{mg} \mathrm{g}^{-1}$ under the initial COD of $1.0 \pm 0.1 \mathrm{~g} \mathrm{~L}^{-1}$ to $1.91 \pm 0.13$ and $2.25 \pm 0.11 \mathrm{mg}$ $\mathrm{g}^{-1}$ under the COD values of $2.0 \pm 0.1$ and $5.0 \pm 0.5 \mathrm{~g} \mathrm{~L}^{-1}$ in the yogurt wastewater, respectively. With the increase of the initial COD from $8.0 \pm 0.6$ to $13.0 \pm 1.0 \mathrm{mg} \mathrm{L}^{-1}$, the anode biomass decreased from $1.89 \pm 0.08$ to $1.65 \pm 0.10 \mathrm{mg} \mathrm{g}^{-1}$. 


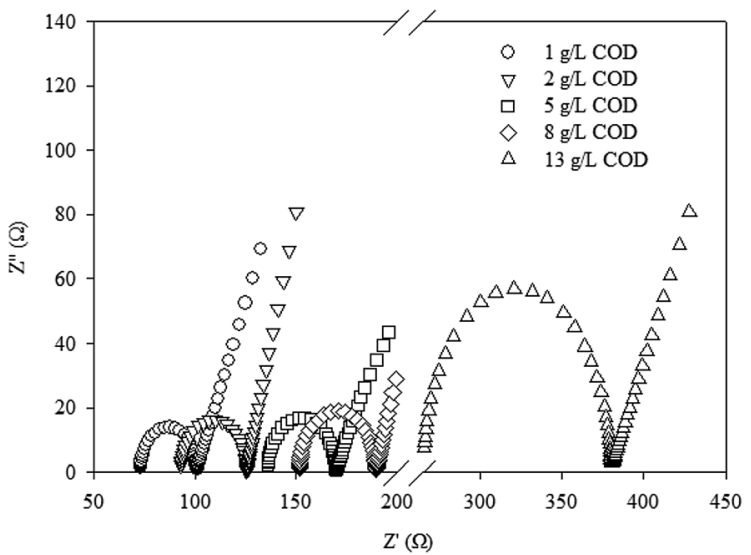

Fig. 3 The EIS measurements on the MFC fed by yogurt wastewater with different COD concentrations.
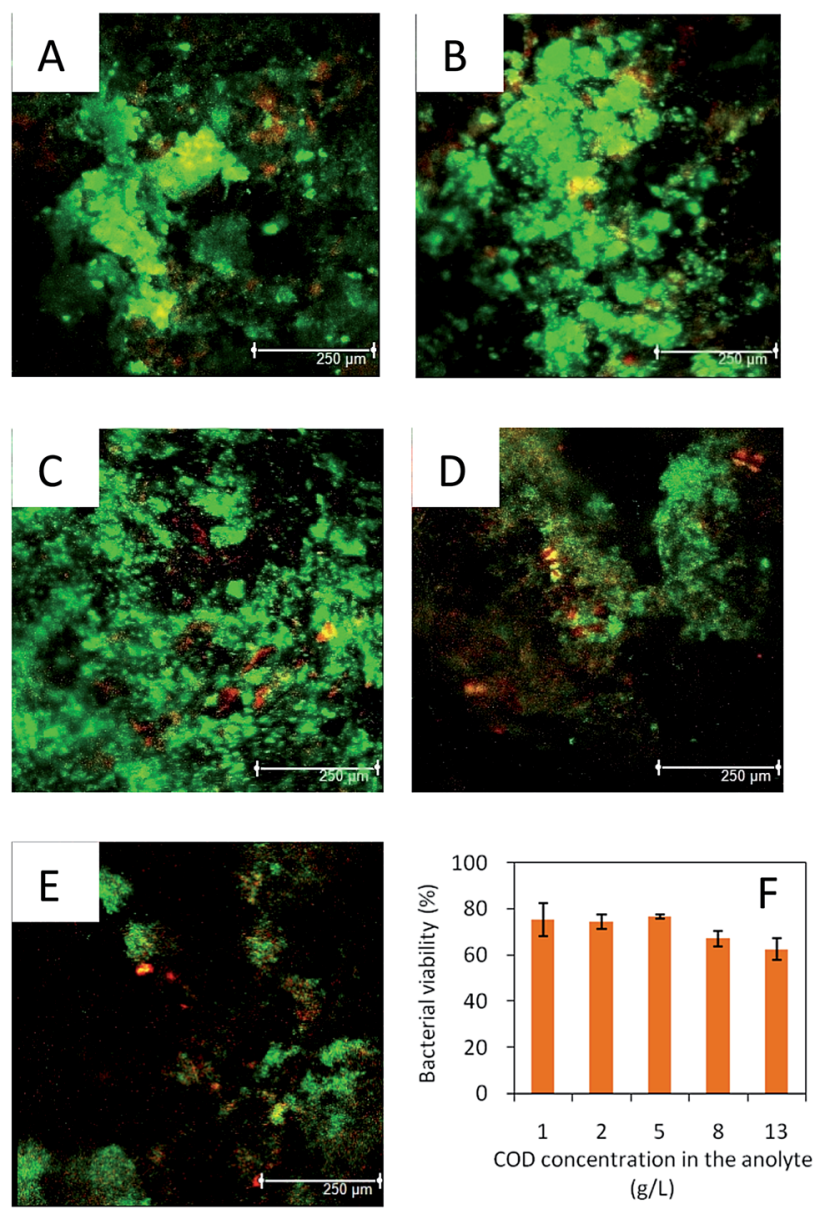

Fig. 4 The CLSM measurements on the anode biofilm in the MFC fed by yogurt wastewater with COD concentrations of (A) $1.0 \pm 0.1 \mathrm{~g} \mathrm{~L}^{-1}$, (B) $2.0 \pm 0.1 \mathrm{~g} \mathrm{~L}^{-1}$, (C) $5.0 \pm 0.5 \mathrm{~g} \mathrm{~L}^{-1}$, (D) $8.0 \pm 0.6 \mathrm{~g} \mathrm{~L}^{-1}$, (E) $13.0 \pm$ $1.0 \mathrm{~g} \mathrm{~L}^{-1}$, and $(\mathrm{F})$ the relation between the bacterial viability and the COD concentrations of yogurt wastewater.

Such high concentrations of organics may inhibit the bacterial growth on the anode and decrease the electricity generation in the MFC. ${ }^{34}$

\subsection{Bacterial community in the anode biofilm of MFC}

The bacterial community in the anode biofilm was identified in the phyla level (Fig. 5). The relative abundance of Proteobacteria in the anode biofilm was $44.5 \%, 57.5 \%, 36.2 \%, 41.3 \%$ and $21.5 \%$ using the yogurt wastewater with COD values of $1.0 \pm 0.1$, $2.0 \pm 0.1,5.0 \pm 0.5,8.0 \pm 0.6$ and $13.0 \pm 1.0 \mathrm{~g} \mathrm{~L}^{-1}$, respectively. The relative abundance of Firmicutes was kept in a range of 19.5-36.8\% with the different yogurt wastewaters in the MFC. Bacteroidetes had the lowest relative abundance of $14.3 \%$ with $1.0 \pm 0.1 \mathrm{~g} \mathrm{~L}^{-1} \mathrm{COD}$ and the highest value of $29.7 \%$ with $13.0 \pm$ $0.1 \mathrm{~g} \mathrm{~L}^{-1} \mathrm{COD}$ in the yogurt wastewater. With the increase of the initial COD concentrations, the relative abundance of Bacteroidetes gradually increased from $10.2 \%\left(2.0 \pm 0.1 \mathrm{~g} \mathrm{~L}^{-1} \mathrm{COD}\right)$ to $22.2 \%\left(8.0 \pm 0.6 \mathrm{~g} \mathrm{~L}^{-1} \mathrm{COD}\right)$, indicating that Bacteroidetes preferred to grow with higher concentrations of organics. Spirochaetae and Synergistetes were identified with the relative abundance of $7.3 \%$ and $4.0 \%$, respectively, in the MFC using $13.0 \pm 1.0 \mathrm{~g} \mathrm{~L}^{-1} \mathrm{COD}$ in the yogurt wastewater. But both Spirochaetae and Synergistetes were less than 1\% in the MFC using $1.0 \pm 0.1 \mathrm{~g} \mathrm{~L}^{-1}$ COD in the yogurt wastewater.

The bacterial community in the anode biofilm was identified in the genus level as shown in Fig. 6. Geoalkalibacter dominated the bacterial community in the anode biofilm throughout all the tests. The relative abundance of Geoalkalibacter was $37.6 \%$, $49.9 \%, 30.1 \%, 39.0 \%$ and $12.9 \%$ in the anode biofilm in the MFC with COD values of $1.0 \pm 0.1,2.0 \pm 0.1,5.0 \pm 0.5,8.0 \pm 0.6$, and $13.0 \pm 1.0 \mathrm{~g} \mathrm{~L}^{-1}$ in the yogurt wastewater, respectively. The relative abundance of Acetoanaerobium was in a range of 6.9$26.4 \%$ in the anode biofilm of MFCs fed by the different COD concentrations in the yogurt wastewater. With the increase of the initial COD concentrations from $1.0 \pm 0.1$ to $13.0 \pm 1.0 \mathrm{~g} \mathrm{~L}^{-1}$ in the yogurt wastewater, the relative abundance of vadinBC27_wastewater-sludge_group increased from $0.6 \%$ to $11.9 \%$, whereas the genus ML635J-40_aquatic_group_norank decreased from $11.5 \%$ to $2.3 \%$. Proteiniphilum and Proteiniclasticum had the highest relative abundance of $6.5 \%$ and $5.4 \%$, respectively, with $13.0 \pm 1.0 \mathrm{~g} \mathrm{~L}^{-1} \mathrm{COD}$ in the yogurt wastewater among all the tests. The Shannon indexes were 2.20, 2.22, 2.73, 2.74, and 3.22 in the MFC with COD values of $1.0 \pm 0.1,2.0 \pm$ $0.1,5.0 \pm 0.5,8.0 \pm 0.6$, and $13.0 \pm 1.0 \mathrm{~g} \mathrm{~L}^{-1}$ in the yogurt

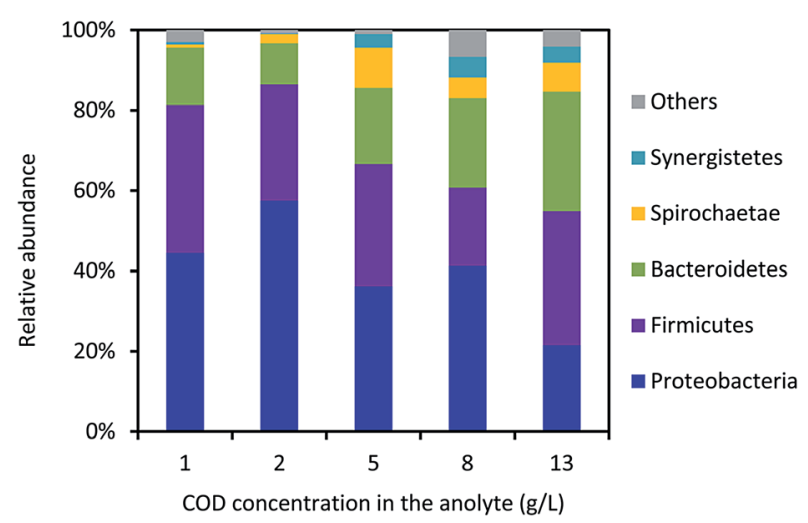

Fig. 5 The bacterial communities in the anode biofilms of MFCs in the phyla level. 


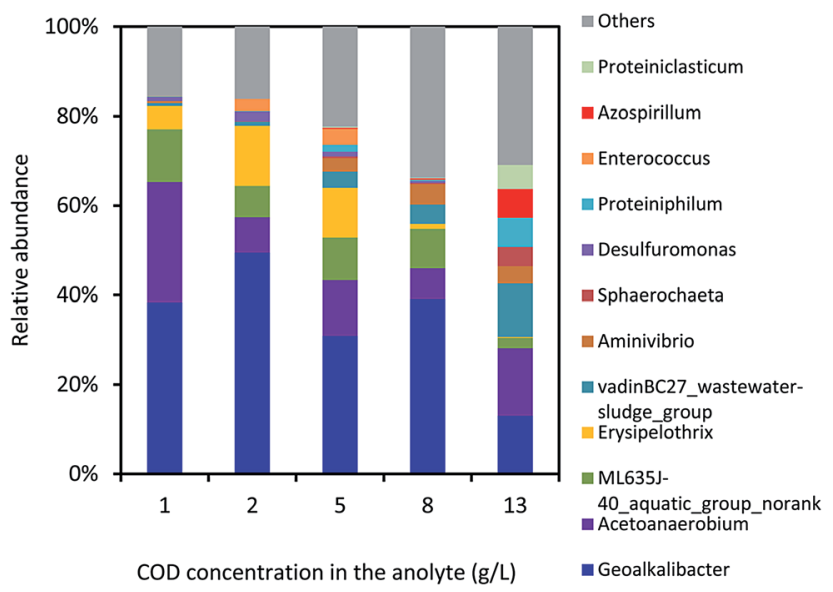

Fig. 6 The bacterial community in the anode biofilm of MFC in the genus level.

wastewater, respectively. The result indicated that higher concentrations of yogurt wastewater could result in higher microbial diversity in the anode biofilm.

Geoalkalibacter is capable of electricity generation and prefers to grow with acetate as substrate under alkaline conditions. ${ }^{\mathbf{9}, \mathbf{1 1}}$ Acetoanaerobium is able to produce acetate and has been widely reported in the anodic biofilm of the MFCs. ${ }^{35,36}$ VadinBC27_wastewater-sludge_group has been identified in the MFC fed with glucose, propyl alcohol or methanol, ${ }^{37}$ or the mesophilic anaerobic digester treating food waste, ${ }^{38}$ indicating that various organics may be degraded by vadinBC27_wastewatersludge_group. ML635J-40_aquatic_group_norank is found to survive under an extreme alkaline salinity condition. ${ }^{39}$ Proteiniphilum and Proteiniclasticum are able to degrade the amino acids under anaerobic condition, ${ }^{38,40,41}$ indicating that high concentration of yogurt wastewater may boost the growth of Proteiniphilum and Proteiniclasticum. Our bacterial community in the anode biofilm in MFC with yogurt wastewater under $\mathrm{pH}=10.5$ was greatly different from that in the MFC with the sole substrate under alkaline conditions, ${ }^{8,9}$ indicating that the type of substrate could significantly affect the bacterial community in the anode biofilm. The electricity generation and degradation of yogurt wastewater in the MFC should be dependent on Geoalkalibacter and various other bacteria with high microbial diversity in the anode biofilm. Nevertheless, the synergistic actions between Geoalkalibacter and various other bacteria need further investigation.

There are many other industrial wastewaters with high alkalinity such as paper making wastewater, petrochemical industry wastewater, etc. ${ }^{\mathbf{4 2 , 4 3}}$ The $\mathrm{pH}$ adjustment in the industrial wastewater is usually needed for the biological treatment, which will consume a lot of acid and increase the operation cost. Therefore, our results should be useful to expand the application scope of MFC in the wastewater treatment under alkaline conditions.

\section{Conclusions}

The electricity generation in the MFC was investigated using yogurt wastewater as the substrate under an alkali condition in this study. With the initial COD concentration of $1.0 \pm 0.1 \mathrm{~g} \mathrm{~L}^{-1}$ and $\mathrm{pH}=10.5$ in the yogurt wastewater, the maximum power density reached $1043 \pm 100 \mathrm{~mW} \mathrm{~m}^{-2}$ in the MFC, which was much higher than those previously reported using foodprocessing wastewater under alkaline conditions. Correspondingly, the COD, $\mathrm{NH}_{4}-\mathrm{N}$, TN removal reached $88 \pm 7 \%, 96 \pm 4 \%$ and $69 \pm 3 \%$, respectively. Higher concentrations of yogurt wastewater increased the internal resistance in the MFC and decreased the bacterial viability in the anode biofilm, resulting in the decrease of the electricity generation in the MFC. Geoalkalibacter with the relative abundance of $12.9-49.9 \%$ was dominant of the bacterial community in the anode biofilm.

\section{Acknowledgements}

This work was partly supported by grants from the National Natural Science Foundation of China (No. 51278500, 41471181, and 51308557), the Natural Science Foundation of Guangdong Province (2015A030313102), and the Fundamental Research Funds for the Central Universities (16lgjc65).

\section{References}

1 P. L. McCarty, J. Bae and J. Kim, Environ. Sci. Technol., 2011, 45, 7100-7106.

2 L. Hsu, B. Chadwick, J. Kagan, R. Thacher, A. Wotawabergen and K. Richter, RSC Adv., 2013, 3, 15947-15954.

3 W. Chen, Y. X. Huang, D. B. Li, H. Q. Yu and L. Yan, RSC Adv., 2014, 4, 21619-21624.

4 Y. Qiao, X. S. Wu, C. X. Ma, H. He and C. Li, RSC Adv., 2014, 4, 21788-21793.

5 B. Cercado-Quezada, M.-L. Delia and A. Bergel, Bioresour. Technol., 2010, 101, 2748-2754.

6 Y. Fan, H. Hu and H. Liu, Environ. Sci. Technol., 2007, 41, 8154-8158.

7 E. Zhang, W. Zhai, Y. Luo, K. Scott, X. Wang and G. Diao, Bioresour. Technol., 2016, 211, 736-742.

8 V. Margaria, T. Tommasi, S. Pentassuglia, V. Agostino, A. Sacco, C. Armato, A. Chiodoni, T. Schilirò and M. Quaglio, Int. J. Hydrogen Energy, 2017, 42, 1820-1829.

9 L. Rago, J. A. Baeza and A. Guisasola, Bioelectrochemistry, 2016, 109, 57-62.

10 Y.-C. Yong, Z. Cai, Y.-Y. Yu, P. Chen, R. Jiang, B. Cao, J.-Z. Sun, J.-Y. Wang and H. Song, Bioresour. Technol., 2013, 130, 763-768.

11 J. P. Badalamenti, R. Krajmalnikbrown and C. I. Torres, mBio, 2013, 4, e00144-13.

12 T. Zhang, L. Zhang, W. Su, P. Gao, D. Li, X. He and Y. Zhang, Bioresour. Technol., 2011, 102, 7099-7102.

13 V. G. Paul, S. D. Minteer, B. L. Treu and M. R. Mormile, Environ. Technol., 2014, 35, 1003-1011.

14 T. Pepe Sciarria, G. Merlino, B. Scaglia, A. D'Epifanio, B. Mecheri, S. Borin, S. Licoccia and F. Adani, J. Power Sources, 2015, 274, 393-399.

15 Q. Wen, Y. Wu, L. Zhao and Q. Sun, Fuel, 2010, 89, 13811385. 
16 K. P. Katuri, A.-M. Enright, V. O'Flaherty and D. Leech, Bioelectrochemistry, 2012, 87, 164-171.

17 M. Mahdi Mardanpour, M. Nasr Esfahany, T. Behzad and R. Sedaqatvand, Biosens. Bioelectron., 2012, 38, 264-269.

18 F. Zhang, D. Pant and B. E. Logan, Biosens. Bioelectron., 2011, 30, 49-55.

19 G. Chen, B. Wei, B. E. Logan and M. A. Hickner, RSC Adv., 2012, 2, 5856-5862.

20 K. Guo, A. H. Soeriyadi, H. J. Feng, A. Prevoteau, S. A. Patil, J. J. Gooding and K. Rabaey, Bioresour. Technol., 2015, 195, 46-50.

21 H. Dong, H. B. Yu, X. Wang, Q. X. Zhou and J. L. Feng, Water Res., 2012, 46, 5777-5787.

22 G. Liu, Y. Zhou, H. Luo, X. Cheng, R. Zhang and W. Teng, Bioresour. Technol., 2015, 198, 87-93.

23 L. S. Clesceri, A. E. Greenberg and A. D. Eaton, Standard methods for the examination of water and wastewater, APHA, Washington, DC, 1998.

24 H. C. Tao, X. N. Sun and Y. Xiong, RSC Adv., 2014, 5, 46594663.

25 Y. Yang, Y. Xiang, C. Xia, W.-M. Wu, G. Sun and M. Xu, Bioresour. Technol., 2014, 164, 270-275.

26 S. T. Read, P. Dutta, P. L. Bond, J. Keller and K. Rabaey, BMC Microbiol., 2010, 10, 98.

27 H. Yan and J. M. Regan, Biotechnol. Bioeng., 2013, 110, 785791.

28 H. Yan, T. Saito and J. M. Regan, Water Res., 2012, 46, 22152224.

29 E. Elakkiya and M. Matheswaran, Bioresour. Technol., 2013, 136, 407-412.
30 S. Venkata Mohan, G. Mohanakrishna, G. Velvizhi, V. L. Babu and P. N. Sarma, Biochem. Eng. J., 2010, 51, 32-39.

31 H. J. Mansoorian, A. H. Mahvi, A. J. Jafari and N. Khanjani, J. Saudi Chem. Soc., 2016, 20, 88-100.

32 A. L. Vázquez-Larios, F. Esparza-García, G. Vázquez-Huerta, O. Solorza-Feria and H. M. Poggi-Varaldo, J. Biotechnol., 2010, 150, 145.

33 Q. Liao, J. Zhang, J. Li, D. Ye, X. Zhu, J. Zheng and B. Zhang, Int. J. Hydrogen Energy, 2014, 39, 19349-19354.

34 H. Luo, S. Yu, G. Liu, R. Zhang and W. Teng, Fuel, 2016, 182, 732-739.

35 K. L. Lesnik and H. Liu, Appl. Microbiol. Biotechnol., 2014, 98, 4187-4196.

36 N. Xafenias and V. Mapelli, Int. J. Hydrogen Energy, 2014, 39, 21864-21875.

37 S. H. Zhang, C. H. Qiu, C. F. Fang, Q. L. Ge, Y. X. Hui, B. Han and S. Pang, Appl. Biochem. Microbiol., 2017, 53, 250-257.

38 L. Li, Q. He, Y. Ma, X. Wang and X. Peng, Bioresour. Technol., 2015, 189, 113-120.

39 Y. Li, J. Cheng, Q. Sun and X. Meng, Fresenius Environ. Bull., 2016, 1827.

40 D. M. Hodgson, A. Smith, S. Dahale, J. P. Stratford, J. V. Li, A. Grüning, M. E. Bushell, J. R. Marchesi and C. A. Rossa, Front. Microbiol., 2016, 7, 699.

41 W. Liu, Z. He, C. Yang, A. Zhou, Z. Guo, B. Liang, C. Varrone and A. J. Wang, Biotechnol. Biofuels, 2016, 9, 83.

42 D. Pokhrel and T. Viraraghavan, Sci. Total Environ., 2004, 333, 37-58.

43 H. Macarie, Water Sci. Technol., 2000, 42, 201-214. 